\title{
Ternary alloy nanocatalysts for hydrogen evolution reaction
}

\author{
SOUMEN SAHA ${ }^{1}$, SONALIKA VAIDYA ${ }^{2}$, KANDALAM V RAMANUJACHARY ${ }^{3}$, \\ SAMUEL E LOFLAND ${ }^{4}$ and ASHOK K GANGULI ${ }^{1,2, *}$ \\ ${ }^{1}$ Department of Chemistry, Indian Institute of Technology, Hauz Khas, New Delhi 110016, India \\ ${ }^{2}$ Institute of Nano Science and Technology, Mohali, Punjab 160062, India \\ ${ }^{3}$ Department of Chemistry and Biochemistry, Rowan University, New Jersey 08028, USA \\ ${ }^{4}$ Department of Physics and Astronomy, Rowan University, New Jersey 08028, USA
}

MS received 23 May 2015; accepted 3 December 2015

\begin{abstract}
Cu}-\mathrm{Fe}-\mathrm{Ni}$ ternary alloys $($ size $\sim 55-80 \mathrm{~nm}$ ) with varying compositions viz. $\mathrm{CuFeNi}(\mathrm{A1}), \mathrm{CuFe} 2 \mathrm{Ni}(\mathrm{A} 2)$ and $\mathrm{CuFeNi}_{2}(\mathrm{A3})$ were successfully synthesized using microemulsion. It is to be noted that synthesis of nanocrystalline ternary alloys with precise composition is a big challenge which can be overcome by choosing an appropriate microemulsion system. High electrocatalytic activity towards HER in alkaline medium was achieved by the formation of alloys of metals with low and high binding energies. A high value of current density $(228 \mathrm{~mA} \mathrm{~cm}$ ) at an overpotential of $545 \mathrm{mV}$ was obtained for $\mathrm{CuFeNi}(\mathrm{A1}$ ), which is significantly high as compared to the previously reported $\mathrm{Ni}_{59} \mathrm{Cu}_{41}$ alloy catalyst.
\end{abstract}

Keywords. Nanostructures; chemical synthesis; electrochemical measurements.

\section{Introduction}

Generation of hydrogen through water splitting is an important area of research. This reaction is not thermodynamically feasible and thus requires a catalyst and external stimuli like light or electricity. Splitting of water using electricity makes this reaction feasible, but requires a catalyst to overcome the kinetic barriers such as low faradaic efficiency and high overpotential associated with it. Thus, a need for efficient electrocatalyst that is an alternative to expensive Pt or Ptbased alloys is necessary. In this paper, we have successfully synthesized nanosized $\mathrm{Cu}-\mathrm{Fe}-\mathrm{Ni}$ ternary alloy with varying stoichiometry $(1: 1: 1,1: 2: 1$ and $1: 1: 2)$ using microemulsion method. One of the key areas in which $\mathrm{Cu}-\mathrm{Fe}-\mathrm{Ni}$ alloy can be applied is the production of hydrogen by splitting water, which has been the prime focus of our group. The ternary system was chosen based on volcano plot. Ni is the most appropriate choice of low-cost catalyst for HER among nonnoble metals in alkaline medium, due to low binding energy which can be observed from the volcano plot [1]. Although $\mathrm{Ni}$ use in acidic media is restricted due to corrosion, it can be used in the alkaline medium as the process of corrosion is insignificant. It has been well established that water splitting in the alkaline medium for the production of pure hydrogen has an advantage due to being environmentally benign, having low cost and being unaffected by poisoning $[1,2]$, which is one of the greatest challenges associated with proton exchange membranes in water electrolysis [3-6]. Taking

\footnotetext{
*Author for correspondence (ashok@ chemistry.iitd.ac.in, director@inst.ac.in)
}

these points into consideration, we have focussed on synthesizing nanostructured ternary alloys; based on $\mathrm{Cu}-\mathrm{Fe}-\mathrm{Ni}$ alloys which includes $\mathrm{Ni}$ as one of the constituent metal and alloyed with two metals, one with weak $\mathrm{M}-\mathrm{H}$ binding energy ( $\mathrm{Fe}$ ) and the other having strong $\mathrm{M}-\mathrm{H}$ binding energy $\mathrm{Cu}$ as observed from the volcano curve $[7,8]$. The aim is to investigate the synergistic effect of these metals on HER.

Synthesis of ternary alloys with desired composition using microemulsions is a big challenge that arises due to number of components taking part in the reaction. Microemulsion method is the most versatile method as there are several parameters associated with the formation of microemulsion viz., solvent, surfactant, co-surfactant and Wo (water to surfactant ratio) that can be optimized to yield particles with desired size and shape. This method involves coalescence of reverse micelles, i.e., exchange of materials between the micelles and de-coalescence of the reverse micelles containing the product. The detailed mechanism is discussed elsewhere [9]. Although there are several techniques that have been used earlier to fabricate ternary nanostructured alloy particles, such as mechanical alloying [10], electrodeposition [11], melt spinning [12], polyol processes [13] and decomposition of organometallic precursors [14], there are only few reports on the synthesis of $\mathrm{Cu}-\mathrm{Fe}-\mathrm{Ni}$ alloy nanoparticles. For instance, Giz et al [15] have fabricated $\mathrm{Ni}-\mathrm{Cu}-\mathrm{Fe}$ alloy using the electrodeposition method. Mechanical alloying method using high-energy ball mill under argon atmosphere was used to synthesize nanostructured copper-iron-nickel alloy with $\left(\mathrm{Cu}_{60} \mathrm{Fe}_{40}\right)_{70} \mathrm{Ni}_{30}$ composition. In addition to the ternary alloy, we obtained BCC-Fe(Ni) solid solutions [16]. $\mathrm{Cu}-\mathrm{Fe}-$ $\mathrm{Ni}$ alloy (20-200 $\mathrm{nm})$ was synthesized by chemical reduction of $\mathrm{Cu}^{2+}, \mathrm{Fe}^{3+}$ and $\mathrm{Ni}^{2+}$ ions with sodium borohydride and 
subsequently treating the precursor at $300-900^{\circ} \mathrm{C}$ in an $\mathrm{H}_{2}$ atmosphere [17].

To the best of our knowledge, there are no reports on the preparation of $\mathrm{Cu}-\mathrm{Fe}-\mathrm{Ni}$ alloy nanoparticles using the microemulsion method. This paper shows the advantage of microemulsion method of synthesis to yield alloy nanoparticles of precise composition which can be varied.

\section{Experimental}

Microemulsion method was employed for the synthesis of $\mathrm{Cu}-\mathrm{Fe}-\mathrm{Ni}$ alloys with varying compositions. We have used cationic surfactant CTAB (cetyltrimethyl ammonium bromide (Spectrochem, AR, 99\%)) along with 1-butanol (Qualigens, 99.5\%) as the co-surfactant and iso-octane (Spectrochem, 99\%) as the oil phase for the formation of microemulsions. Five microemulsions containing $0.1 \mathrm{M}$ $\mathrm{Cu}\left(\mathrm{NO}_{3}\right)_{2} \cdot 3 \mathrm{H}_{2} \mathrm{O}, 0.1 \mathrm{M} \mathrm{Ni}\left(\mathrm{NO}_{3}\right)_{2} \cdot 6 \mathrm{H}_{2} \mathrm{O}, 0.1 \mathrm{M} \mathrm{Fe}\left(\mathrm{NO}_{3}\right)_{2} \cdot 9$ $\mathrm{H}_{2} \mathrm{O}, 1 \mathrm{M} \mathrm{N}_{2} \mathrm{H}_{4} \cdot \mathrm{H}_{2} \mathrm{O}$ and $0.1 \mathrm{M} \mathrm{NaOH}$ were formed. The weight fraction of CTAB in the microemulsion was $16.76 \%$ with $13.9 \%$ 1-butanol, $59.29 \%$ iso-octane and $10.05 \%$ of aqueous solution. The microemulsions were mixed and stirred for $24 \mathrm{~h}$. The brown-coloured product was separated by centrifugation and washed with a mixture of chloroform and methanol (1:1). The obtained product was dried in air and heated at $700^{\circ} \mathrm{C}$ for $5 \mathrm{~h}$ in $\mathrm{H}_{2}$ atmosphere. Three different compositions were loaded for $\mathrm{Cu}-\mathrm{Fe}-\mathrm{Ni}$ in the ratio of $1: 1: 1$, $1: 2: 1$ and $1: 1: 2$, referred as $\mathrm{A} 1, \mathrm{~A} 2$ and $\mathrm{A} 3$, respectively.

To obtain structural information and phase purity of the synthesized nanoalloys, powder X-ray diffraction was carried out on a Bruker D8 Advance diffractometer with a Nifiltered $\mathrm{CuK} \alpha$ radiation $(\lambda=1.5418 \AA$ ). The data were recorded with $2 \theta$ values from 35 to $100^{\circ}$ at a scanning rate of $0.02^{\circ} \mathrm{s}^{-1}$. Refinement of lattice parameters was carried out with Powder Cell software [18].

Transmission electron microscopy (TEM) and bright field scanning transmission electron microscopy (BF-STEM) with a Technai $\mathrm{G}^{2} 20$ electron microscope operating at $200 \mathrm{kV}$ were used. STEM-EDX measurements were carried out to analyse the distribution of $\mathrm{Fe}, \mathrm{Co}$ and $\mathrm{Ni}$ atoms in the particle interior. The samples were prepared by dispersing the powder sample in absolute ethanol by ultrasonic treatment, adding a drop of this dispersion on the copper grid having porous carbon film support, and then drying in air. EDX studies were also carried out on a Hitachi TM 3000 SEM. Powder samples were mounted on a carbon tape attached on a circular metallic sample holder.

Cyclic voltammetric studies were carried out to study the hydrogen evolution reaction at room temperature with an electrochemical workstation (Autolab PGSTAT 302N). The cell consists of three electrode system $\mathrm{Ag} / \mathrm{AgCl} / \mathrm{KCl}$ (3 M $\mathrm{KCl}$ ) as reference electrode (RE), Pt rod as a counter electrode $(\mathrm{CE})$ and a glassy carbon electrode (GCE; Metrohm, $2 \mathrm{~mm}$ diameter, $0.031 \mathrm{~cm}^{2}$ ) modified with CuFeNi alloys as working electrode. The reported potentials in this paper were $v s$. the reversible hydrogen electrode which were calculated using the following equation [19]:

$$
\begin{aligned}
E(\mathrm{RHE})= & E(\mathrm{Ag} / \mathrm{AgCl}(3 \mathrm{M} \mathrm{KCl})) \\
& +E^{0}(\mathrm{Ag} / \mathrm{AgCl}(3 \mathrm{M} \mathrm{KCl}))+0.059 \mathrm{pH} \\
= & E(\mathrm{Ag} / \mathrm{AgCl}(3 \mathrm{M} \mathrm{KCl}))+0.210 \mathrm{~V} \\
& +0.059 \times 12.7(\mathrm{pH} \text { at } 0.5 \mathrm{KOH} \text { is } \sim 12.7) \\
= & E(\mathrm{Ag} / \mathrm{AgCl}(3 \mathrm{M} \mathrm{KCl}))+0.959 \mathrm{~V} .
\end{aligned}
$$

The GCE before modification was polished with alumina powder $(0.05 \mu \mathrm{m})$, ultrasonicated in distilled water followed by ethanol, and then dried in an oven. Analytical grade reagents were used for the preparation of solution from double distilled water. Cyclic voltammetry was carried out with blank GC electrode in $0.5 \mathrm{M} \mathrm{KOH}$ solution at a potential range from -1.5 to $0 \mathrm{~V}$ until a stable voltammogram was obtained. The solution was degassed by purging $\mathrm{N}_{2}$ for half an hour. All experiments were conducted at $25^{\circ} \mathrm{C}$. Modified electrodes were prepared from the dispersion of $2 \mathrm{mg}$ of the alloy nanoparticles with $15 \mu \mathrm{l}$ of isopropanol and $10 \mu \mathrm{l}$ of Nafion in ethanol solution $(5 \mathrm{wt} \%$ in lower aliphatic alcohols and water). Five microlitres of this dispersion was pasted on GC and the solvent was evaporated in an oven for half an hour. To remove unbound suspension that may interfere with the voltammograms during the measurement, the $\mathrm{Cu}-$ $\mathrm{Fe}-\mathrm{Ni} / \mathrm{GC}$ electrodes were washed again with distilled water. The cyclic voltammetry was recorded in the potential range from -1.5 to $0 \mathrm{~V}$ at a scan rate of $25 \mathrm{mV} \mathrm{s}^{-1}$ (figure 4). The current density was normalized with respect to geometric electrode surface area [1].

\section{Results and discussion}

The precursor of the ternary alloy $(\mathrm{Cu}-\mathrm{Fe}-\mathrm{Ni})$ obtained at room temperature was found to be amorphous by XRD. After annealing at $700^{\circ} \mathrm{C}$ for $5 \mathrm{~h}$ under hydrogen atmosphere, three sharp peaks were observed in the diffraction patterns (figure 1). Diffraction peaks were indexed to (111), (200) and (220) planes with respect to the fcc cubic lattice of $\mathrm{Cu}-\mathrm{Fe}-\mathrm{Ni}$ system. The lattice parameters were calculated as 3.573(4) $\AA$, 3.570 (7) $\AA$ and 3.559 (3) $\AA$ for A1, A2 and A3, respectively.

TEM studies were carried out to further investigate the shape and size of the formed alloy. Figure $2 \mathrm{a}-\mathrm{c}$ showed the formation of nanoparticles with spherical shape having size of $70-80,65-75$ and $55-60 \mathrm{~nm}$ for A1, A2 and A3, respectively. EDX studies confirmed that the observed compositions were in accordance to the loaded ones (table 1). Electron diffraction studies indicated polycrystalline nature of the sample (A3) (figure 2d) and was found to match well with fcc structure of the alloy. Homogeneous distribution of $\mathrm{Cu}, \mathrm{Fe}$ and $\mathrm{Ni}$ in the alloy was observed using the STEM mapping (figure $3 \mathrm{a}-\mathrm{d}$ ).

We have carried out HER studies in basic medium, in which the reaction was as follows:

$$
\begin{aligned}
& \mathrm{M}+\mathrm{H}_{2} \mathrm{O}+\mathrm{e}^{-} \longrightarrow \mathrm{M}-\mathrm{H}_{\mathrm{ads}}+\mathrm{OH}^{-} \\
& \mathrm{M}-\mathrm{H}_{\mathrm{ads}}+\mathrm{H}_{2} \mathrm{O}+\mathrm{e}^{-} \longrightarrow \mathrm{H}_{2}+\mathrm{OH}^{-}+\mathrm{M}
\end{aligned}
$$




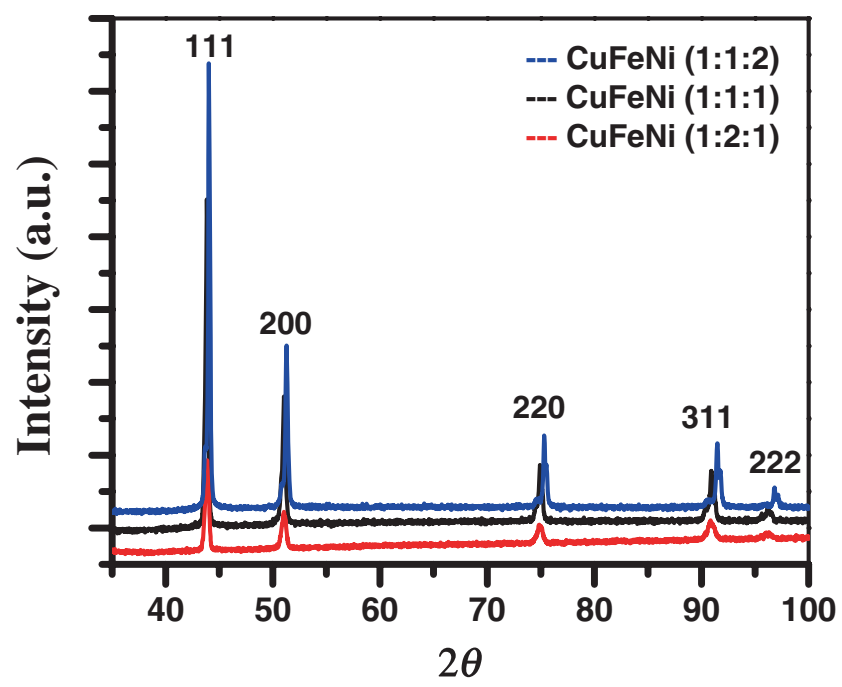

Figure 1. Powder X-ray diffraction patterns of (a) A1, (b) A2 and (c) A3 alloy nanoparticles.

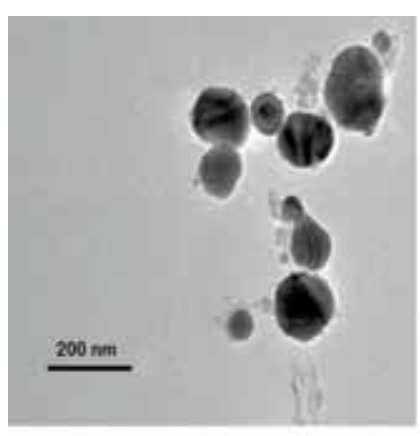

(a)

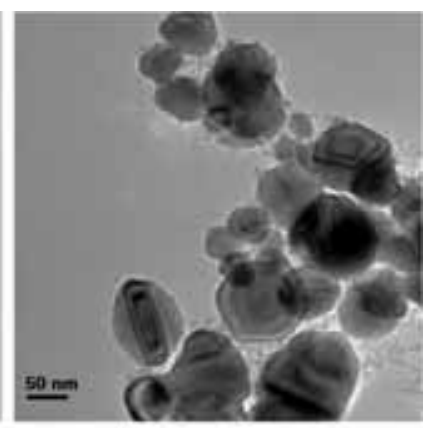

(b)

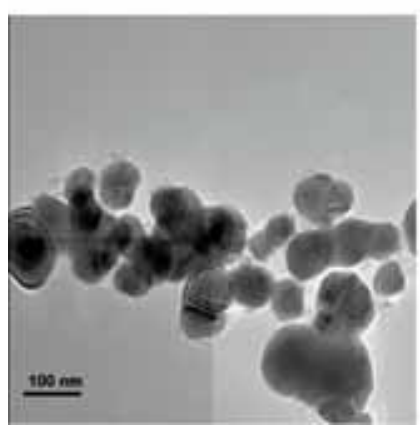

(c)

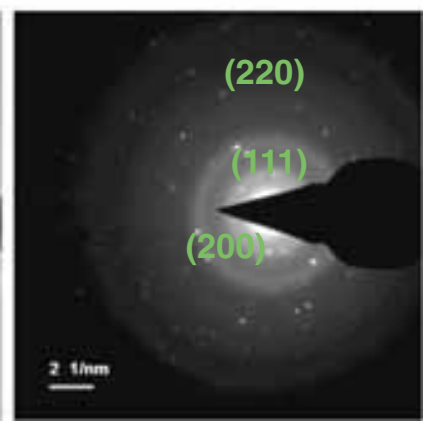

(d)

Figure 2. TEM micrographs of (a) A1, (b) A2, (c) A3 and (d) ED pattern of polycrystalline A3 alloy nanoparticles.

where $\mathrm{M}$ is the electrocatalyst. The overall reaction is

$$
2 \mathrm{H}_{2} \mathrm{O}+2 \mathrm{e}^{-} \longrightarrow \mathrm{H}_{2}+2 \mathrm{OH}^{-} .
$$

The current density for A1/GC, A2/GC and A3/GC electrodes was calculated by dividing observed current with geometric area of the electrode and found to be 228, 164 and $152 \mathrm{~mA} \mathrm{~cm}^{-2}$ with an onset potential range of -0.25 to $-0.20 \mathrm{~V}$ (vs. RHE) and also followed the same order as
Table 1. The EDS analysis of $\mathrm{Cu}-\mathrm{Fe}-\mathrm{Ni}$ alloy nanoparticles (error: $3-5 \%$ ).

\begin{tabular}{lcc}
\hline Sample & Loaded composition & Observed composition \\
\hline A1 & $\mathrm{Cu}_{33} \mathrm{Fe}_{33} \mathrm{Ni}_{33}$ & $\mathrm{Cu}_{34} \mathrm{Fe}_{30} \mathrm{Ni}_{36}$ \\
A2 & $\mathrm{Cu}_{25} \mathrm{Fe}_{50} \mathrm{Ni}_{25}$ & $\mathrm{Cu}_{22} \mathrm{Fe}_{44} \mathrm{Ni}_{34}$ \\
A3 & $\mathrm{Cu}_{25} \mathrm{Fe}_{25} \mathrm{Ni}_{50}$ & $\mathrm{Cu}_{26} \mathrm{Fe}_{26} \mathrm{Ni}_{48}$ \\
\hline
\end{tabular}

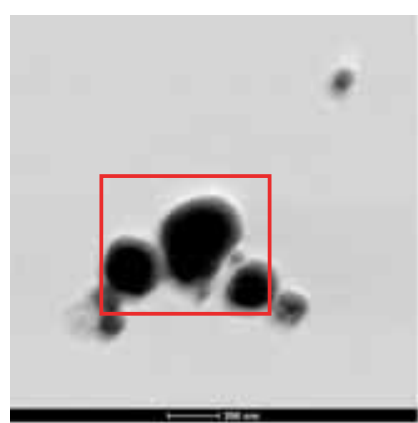

(a)

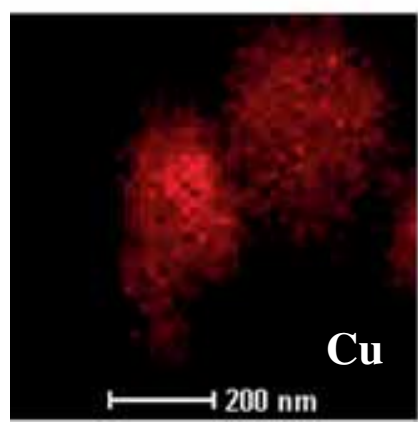

(c)

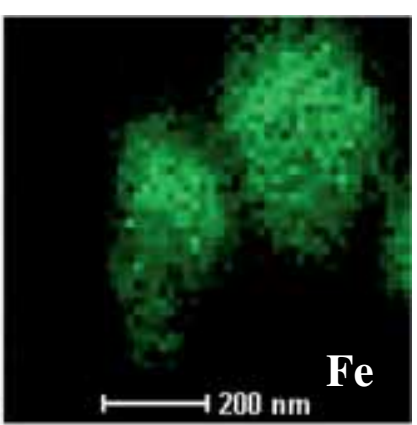

(b)

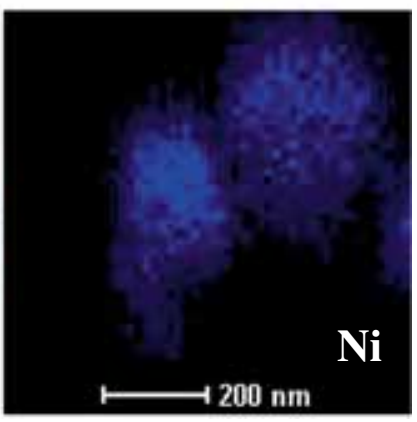

(d)
Figure 3. (a) STEM micrograph and (b-d) elemental mapping images of A1 nanoalloy.

$\mathrm{A} 1 / \mathrm{GC}>\mathrm{A} 2 / \mathrm{GC}>\mathrm{A} 3 / \mathrm{GC}$ (figure 4). The normalized current density value obtained for $\mathrm{Cu}-\mathrm{Fe}-\mathrm{Ni}$ alloys is higher than the recent report for $\mathrm{Ni}_{59} \mathrm{Cu}_{41}\left(\sim 170 \mathrm{~mA} \mathrm{~cm}{ }^{-2}\right)$ [1], $\mathrm{Cu} / \mathrm{CuNi}\left(55 \mathrm{~mA} \mathrm{~cm}^{-2}\right)$ [20], Fe-Co $\left(\sim 40 \mathrm{~mA} \mathrm{~cm}^{-2}\right)$ [21] or $\mathrm{Cu}-\mathrm{Co}\left(\sim 15 \mathrm{~mA} \mathrm{~cm}^{-2}\right)$ in $0.5 \mathrm{M} \mathrm{KOH}$ [22] and Ni-Fe $\left(\sim 120 \mathrm{~mA} \mathrm{~cm}^{-2}\right)$ in $0.5 \mathrm{~mol} \mathrm{l}^{-1} \mathrm{NaCl}$ [23].

For the reaction

$2 \mathrm{H}_{2} \mathrm{O}+2 \mathrm{e}^{-} \longrightarrow \mathrm{H}_{2}+2 \mathrm{OH}^{-}$,

the value of $E_{\mathrm{e}}^{0}=-0.83 \mathrm{~V}$ (standard value). Since HER was carried out in $0.5 \mathrm{M} \mathrm{KOH}$, using the Nernst equation, the theoretical potential at which the reaction is expected to occur was calculated to be $-0.812 \mathrm{~V}$. The onset potential for A1, $\mathrm{A} 2$ and $\mathrm{A} 3$ was observed at $-0.24,-0.20$ and $-0.21 \mathrm{~V}$, respectively. The overpotential was calculated using the following equation [24].

$$
\eta=E-E_{\mathrm{e}}^{0}+\frac{R T}{n F} \ln c_{\mathrm{OH}^{-}}^{2}
$$




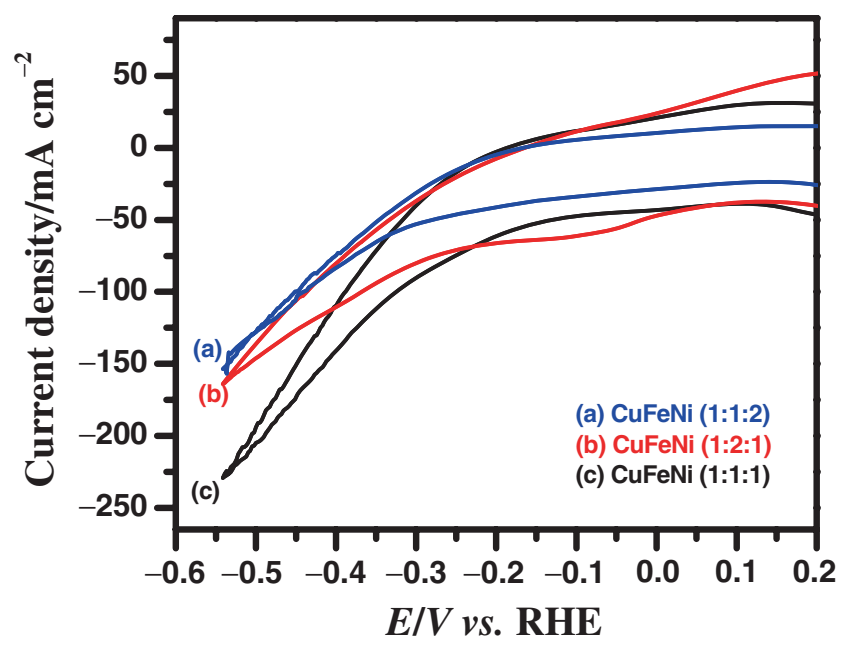

Figure 4. Cyclic voltammogram of hydrogen evolution reaction using A1/GC, A2/GC and A3/GC electrodes in 0.5 M KOH solution at a scan rate of $25 \mathrm{mV} \mathrm{s}^{-1}$.

Thus, the overpotential was calculated to be 545,565 and 573 $\mathrm{mV}$ for $\mathrm{A} 1, \mathrm{~A} 2$ and $\mathrm{A} 3$, respectively, which is lower than the recent report for $\mathrm{Ni}_{59} \mathrm{Cu}_{41}$ catalyst $(-1.6 \mathrm{~V} v$ s. $\mathrm{SCE})$ in $6 \mathrm{M}$ $\mathrm{KOH}[1]$.

\section{Conclusions}

Spherical nanoparticles of ternary alloys of $\mathrm{Cu}-\mathrm{Fe}-\mathrm{Ni}$ with varying composition were successfully synthesized using microemulsion method. The size of alloy nanoparticles varied from 60 to $80 \mathrm{~nm}$. Synergistic effect of the metals (with low and high binding energies) by the formation of alloys resulted in the high electrocatalytic activity of the alloy towards HER in alkaline medium. Among the three compositions of $\mathrm{Cu}-\mathrm{Fe}-\mathrm{Ni}$ alloys, a notable high current density value of $228 \mathrm{~mA} \mathrm{~cm}^{-2}$ with an onset potential of $-0.267 \mathrm{~V}$ and an overpotential of $545 \mathrm{mV}$ was observed for $\mathrm{CuFeNi}$ $(1: 1: 1)$.

\section{Acknowledgements}

This work was financially supported by DST (Nanomission) and DeiTY, Govt. of India. Saha thanks CSIR for fellowship. SEL and KVR thank the Dean, College of Science and Mathematics, for granting release time to conduct part of the work reported here.

\section{References}

[1] Ahn S H, Park H Y, Choi I, Yoo S J, Hwang S J, Kim H J, Cho E, Yoon C W, Park H, Son H, Hernandez J M, Nam S W, Lim T H, Kim S K and Jang J H 2013 Int. J. Hydrogen Energy 3813493

[2] Lu G, Evans P and Zangari G 2003 J. Electrochem. Soc. 150 A551

[3] Santos D M F, Sequeira C A C, Macciò D, Saccone A and Figueiredo J L 2013 Int. J. Hydrogen Energy 383137

[4] Lubitz B and Tumas W 2007 Chem. Rev. 1073900

[5] Barbaro C B P 2009 Catalysis for Sustainable Energy Production (Wiley-VCH: Weinheim)

[6] Vielstich G W, Lamm A, Vielstich H W, Lamm A and Gasteiger H 2003 Handbook of Fuel Cells: Fundamentals, Technology and Applications (Chichester: Wiley)

[7] Conway B E and Bockris J O 1957 J. Chem. Phys. 26532

[8] Greeley J, Jaramillo T F, Bonde J, Chorkendorff I B and Nørskov J K 2006 Nat. Mater. 5909

[9] Ganguli A K, Ganguly A and Vaidya S 2010 Chem. Soc. Rev. 39474

[10] Mondal B N, Basumallick A and Chattopadhyay P P $2008 \mathrm{~J}$. Alloys Compd. 45710

[11] Wang C, Li W, Lu X, Xie S, Xiao F, Liu P and Tong Y 2012 Int. J. Hydrogen Energy 3718688

[12] Curiotto S, Johnson E, Celegato F, Coisson M and Pryds N 2009 J. Magn. Magn. Mater. 321131

[13] Toneguzzo P, Viau G, Acher O, Guillet F, Bruneton E, FievetVincent F and Fievet F 2000 J. Mater. Sci. 353767

[14] Luo J, Wang L, Mott D, Njoki P N, Kariuki N, Zhong C-J and He T 2006 J. Mater. Chem. 161665

[15] Giz M J, Marengo M C, Ticianelli E A and Gonzalez E R 2003 Eclet. Quim. 2821

[16] Slimi M, Azabou M, Escoda L, Suñol J J and Khitouni M 2014 Powder Technol. 266262

[17] Stolk J and Manthiram A 1999 Mater. Sci. Eng. B 60112

[18] Kraus W 2000 Nolze G Version 2.4, Berlin

[19] Gao M-R, Cao X, Gao Q, Xu Y-F, Zheng Y-R, Jiang J and Yu S-H 2014 ACS Nano 83970

[20] Solmaz R, Doner A and Kardas G 2008 Electrochem. Commun. 101909

[21] Ahmed J, Kumar B, Mugweru A M, Trinh P, Ramanujachary K V, Lofland S E and Ganguli A K 2010 J. Phys. Chem. C 11418779

[22] Ahmed J, Ganguly A, Saha S, Gupta G, Trinh P, Mugweru A M, Lofland S E, Ramanujachary K V and Ganguli A K 2011 J. Phys. Chem. C 11514526

[23] Song Li-Jun and Meng H-M 2010 Acta Phys.-Chim. Sin. 26 2375

[24] Greef R, Peat R, Peter L, Pletcher D and Robinson J 1985 Instrumental Methods in Electrochemistry (Chichester: Ellis Horwood Ltd) 